\title{
SOME ASPECTS OF THE DEVELOPMENT AND PERFORMANCE OF 'CRASSLANDS 4700' WHITE CLOVER
}

\author{
P. C. BARClay \\ Grasslands Division, DSIR, Palmerston N orth
}

\section{Summary}

A brief outline is given of the breeding of the new clover 'Grasslands 4700'. Reports are made on the performance of 4700 as single plants at Kaikohe, Palmerston North: Lincoln and Gore, and as mown swards with associated grasses at Palmerston North. In all trials, 4700 was superior to Huia in winter, and equal to or better than Huia in the summer, except at Lincoln where it was inferior. Based on these results seed was released for widespread trials in order to assess its regional adaptation and its performance in mixed swards under different systems of management.

The grazing trial at Palmerston North reports interim information that indicates superior ryegrass, clover and total production in winter, associated with the new clover. Over two complete years, 4700 is associated with a clover superiority of $33 \%$ and a total increase of $17 \%$ compared with Huia pasture.

The ratio of clover to grass associated with 4700 is discussed. The difference in D.M. per acre per day for 4700 growth at Palmcrston North and Gore is discussed and the possible significance of this emphasized.

IN 1957, selected plants of a Spanish introduction with excellent winter growth and poor summer growth at Palmerston North were crossed with elite New Zealand plants which had poor winter growth and excellent summer growth. The intention was to combine, in so far as was possibe, the good characteristics of each line, and breed a new variety of good type that would have improved cool season production compared with certified New Zealand white clover and also provide more $\mathrm{N}$ for the associated grass. Progress reports on the 1st generation progenies and subsequent backcross progenies were made by Barclay $(1960,1963)$. In 1962 a polycross was made using, one plant from each of the best 62 progenies of the 135 backcross progenies being assessed, all or in part, at the four stations of Grasslands, Division Kaikohe, Palmerston North, Lincoln and Gore. This paper reports the per- 
TABLE 1: WHITE CLOVER PRODUCTION, KAIKOHE SINGLE PLANTS

\begin{tabular}{|c|c|c|c|c|}
\hline & $\begin{array}{r}S u m m e r \\
29 / 1 / 64\end{array}$ & $\begin{array}{l}\text { Winter } \\
25 / 8 / 64\end{array}$ & $\begin{array}{r}\text { Summer } \\
8 / 3 / 65\end{array}$ & \\
\hline Huia & 100 & 100 & 100 & \\
\hline 4700 & \begin{tabular}{c|c} 
NS \\
102 \\
$* * *$
\end{tabular} & \begin{tabular}{r|r}
$* *$ & \\
140 & NSS
\end{tabular} & $\begin{array}{l}\text { NS } \\
105 \\
* *\end{array}$ & ** \\
\hline Spain & 64-1 & $81-1$ & 56_ & \\
\hline SE & \pm 6 & \pm 7 & \pm 6 & \\
\hline
\end{tabular}

TABLE 2: WHITE CLOVER PRODUCTION, PALMERSTON NORTH SINGLE PLANTS

\begin{tabular}{|c|c|c|c|c|}
\hline & $\begin{array}{l}\text { Summer } \\
26 / 2 / 64\end{array}$ & $\begin{array}{c}\text { Winter } \\
22 / 7 / 64\end{array}$ & \multicolumn{2}{|c|}{$\begin{array}{l}\text { Spring } \\
3 / 11 / 64\end{array}$} \\
\hline Huia & $100-$ & $\underset{* *}{100}$ & $\begin{array}{l}100- \\
\text { NS }\end{array}$ & \\
\hline 4700 & $\begin{array}{c}119 \\
* *\end{array}$ & $\begin{array}{l}321 \\
\text { NS }\end{array}$ & $\begin{array}{r}104 \\
* *\end{array}$ & $* *$ \\
\hline Spain & $77-$ & $327-$ & $67-$ & \\
\hline SE & \pm 7 & \pm 24 & \pm 9 & \\
\hline
\end{tabular}

TABLE 3: WHITE CLOVER PRODUCTION, LINCOLN SINGLE PLANTS

\begin{tabular}{ccc}
\hline & $\begin{array}{c}\text { Summer } \\
28 / 1 / 64\end{array}$ & $\begin{array}{c}\text { Winter } \\
27 / 7 / 64\end{array}$ \\
\hline Huia & $100-\mid$ & $100-1$ \\
& $* *$ & $\left.136\right|^{* *}$ \\
4700 & $\left.86\right|^{* *}$ & NS \\
Spain & NS & $127-1$ \\
SE & $90-$ & \pm 3 \\
\hline
\end{tabular}

TABLE 4: WHITE CLOVER PRODUCTION, GORE SINGLE PLANTS

\begin{tabular}{|c|c|c|c|c|c|}
\hline \multirow[b]{2}{*}{ Huia } & \multicolumn{2}{|c|}{$\begin{array}{l}\text { Summer } \\
6 / 4 / 64\end{array}$} & \multicolumn{2}{|c|}{$\begin{array}{c}\text { Winter } \\
: \quad 26 / 8 / 64\end{array}$} & $\underset{4 / 3 / 65}{S u m m e r}$ \\
\hline & $1_{* *} 0$ & o - & $100-$ & & $\begin{array}{l}100- \\
\text { NS }\end{array}$ \\
\hline 4700 & $\begin{array}{c}124 \\
* *\end{array}$ & NS & $\begin{array}{r}1.41 \\
* *\end{array}$ & * & $\begin{array}{r}107 \\
* *\end{array}$ \\
\hline Spain & 98 & & 80 & & $68-$ \\
\hline SE & \pm & & \pm 6 & & \pm 4 \\
\hline
\end{tabular}


formance of the bulked seed of this polycross and/or its derivatives, all of which are now called 'Grasslands 4700', as single spaced plants at the four stations and as mown plots and grazed swards with associated grasses at Palmerston North.'

\section{SINGLE PLANT TRIALS}

Tables 1, 2, 3 and 4 compare 4700 with the parent lines Spain and 'Grasslands Huia' at the 4 Grasslands stations for selected growth periods as single plants spaced at $2 \mathrm{ft}$ centres.

Spain was poorer than Huia in summer and winter at Kaikohe and Gore. At Palmerston North and Lincoln, Spain was better in winter but generally poorer in the warmer seasons.

4700 was significantly better than Huia in the winter at all four locations (Fig. 1). In the summer the situation was variable. At Kaikohe, 4700 and Huia did not differ. 4700 was significantly better than Huia at Palmerston North and significantly worse at Lincoln. At Gore in the first summer, 4700 was significantly better than Huia but the two clovers did not differ in the second summer.

The number of days' growth for the winter periods was 60 at Kaikohe, 97 at Palmerston North, 104 at Lincoln and 142 at Gore.

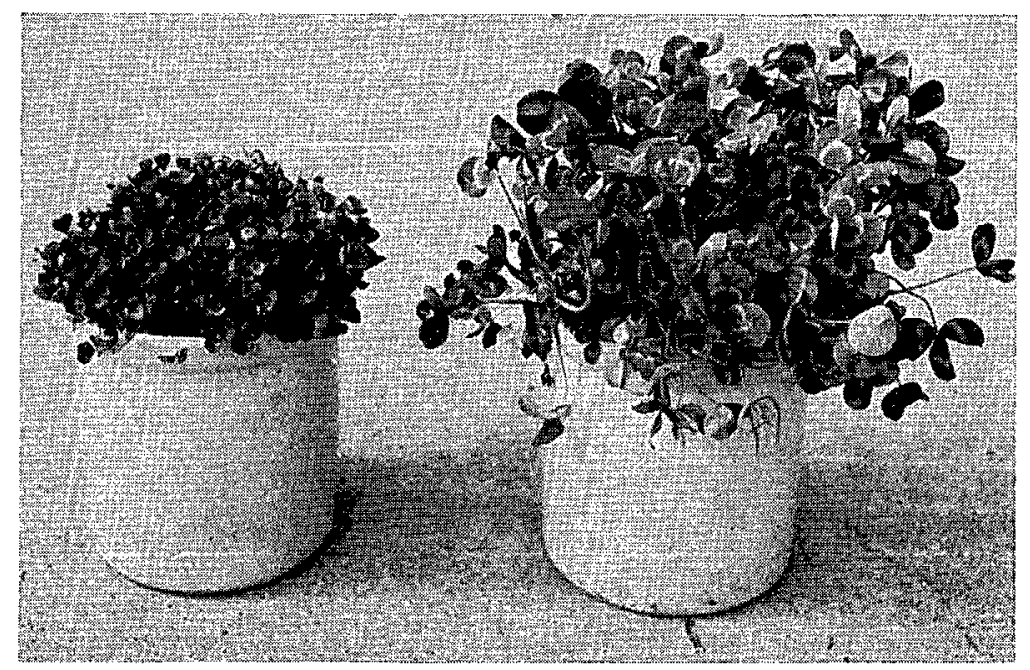

FIG. 1: Single plants of Huia (left) and 4700 (right) dug from the field in Palmerston North, July 1964. 


\section{MOWING TRIAL, PALMERSTON NORTH}

As sufficient seed of 4700 from the 1962 polycross was available, a mowing trial was sown at Palmerston North in autumn 1963 comparing 4700 and Huia each in a mixed sward with either 'Grasslands Ruanui' perennial ryegrass, 'Grasslands Ariki' hybrid ryegrass, or 'Grasslands Manawa' hybrid ryegrass. Tables, 5,6 and 7 show dry matter production per acre for summer 1964-5, winter 1965 and spring 1965, for both clover and ryegrass production.

TABLE 5: WHITE CLOVER MOWING TRIAL

(lb Dry Matter Per Acre)

SUMMER

$(10 / 12 / 64-26 / 2 / 65)$

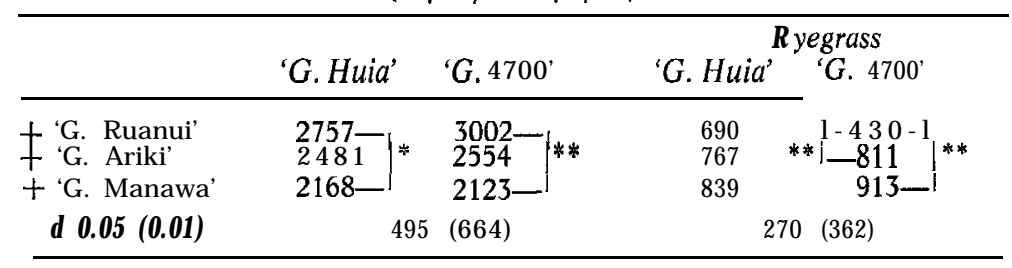

TABLE 6: WHITE CLOVER MOWING TRIAL

(lb Dry Matter Per Acre)

WINTER

$(11 / 5 / 65-2 / 9 / 65)$

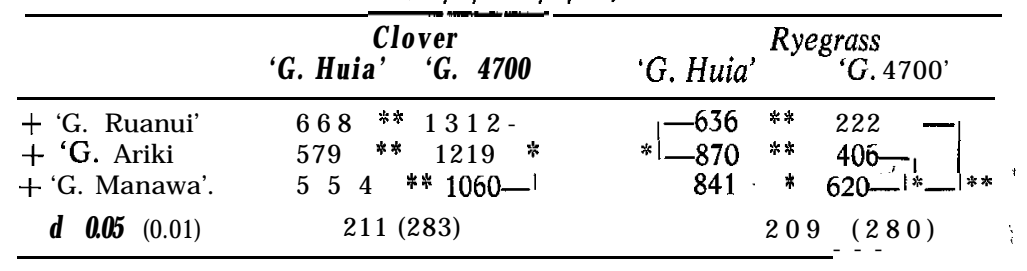

TABLE 7: WHITE CLOVER MOWING TRIAL

(lb Dry Matter Per Acre)

SPRING

$(2 / 9 / 65-14 / 12 / 65)$

\begin{tabular}{|c|c|c|}
\hline & Clover & Ryegrass \\
\hline & 'G. Huia' 'G.4700 & 'G. Huia' 'G. 4700 ' \\
\hline $\begin{array}{l}+ \text { 'G. R u a n u } \\
+ \text { 'G. Ariki } \\
+ \text { 'G. M a n a w a' }\end{array}$ & 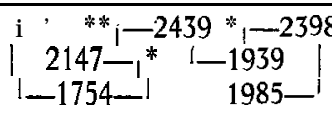 & $* *\left|\begin{array}{r}-1378- \\
1980- \\
-2033\end{array} * *\right| \begin{array}{r}1055-\mid \\
2050 \_ \\
-1907\end{array} \mid * *$ \\
\hline d $0.05(0.01)$ & $(454)$ & $381(511)$ \\
\hline
\end{tabular}


In two summers there were no significant differences between 4700 and Huia plots for either clover or ryegrass content within ryegrass varieties. In winter, with each ryegrass, 4700 production was highly significantly greater than Huia, the increase being about $100 \%$. Associated with the increased growth of 4700 is a highly significant decrease in ryegrass content. Between ryegrass varieties in summer and winter there were significant differences in both clover and ryegrass content. These in general may be explained by seasonal production. However, in the first summer, with 4700 , the Ariki plots are highly significantly greater in ryegrass content than the Ruanui and this difference is not significant with Huia. This would be explained if 4700 were more competitive with Ruanui than with Ariki. Even though the swards became strongly clover dominant, common for mown plots without added $\mathrm{N}$ or return of clippings, a comparison of the mean total production in lb D.M. per acre of grass + clover, combining data for all three ryegrasses is pertinent. 4700 plots are not significantly different to Huia in either summer, the production being, respectively, 3,278 lb D.M. per acre to 3,234 lb in the first summer and $3,910 \mathrm{lb}$ to $3,778 \mathrm{lb}$ in the second summer. However, in the winter, 4700 plots are highly significantly better than Huia plots, the production being $4,839 \mathrm{lb}$ to $4,148 \mathrm{lb}$, an increase of $17 \%$.

Thus, with single plants at four stations and with mown swards at Palmerston North, 4700 outyielded Huia in winter. It should be noted that for the single plants the winter growth period was 142 days at Gore compared with 60 days at Kaikohe. It is likely that, in places with a long winter, superiority of 4700 over Huia in this season would mean little in terms of valuable winter production,

The fact that in mown plots in winter the increased growth of 4700 was associated with a corresponding decrease in ryegrass content, indicated the likelihood that 4700 was more competitive than Huia with grass, and it was essential to determine whether this happened in grazed swards.

It was considered that the results indicated that more widespread trials should be carried out and that, where feasible, grazing trials in association with grasses were desirable. Accordingly it was decided to increase seed for further trials. A bulk of seed, from 37 of the 62 plants in the 1962 polycross that had superior progenies in a single plant test at Palmerston North, was used for this purpose and single plants were grown at Lin- 
coln for seed production. This third generation seed was released for the early trials and some fourth generation seed pro duced in Otago was released later. The different generations are being studied for trueness to type. Seed was released to Grasslands Division officers for trials at all four stations, to the Department of Agriculture for trials at Ruakura and Invermay, and by the Field Research Section on a New Zealand-wide basis. Seed was also released to Massey No. 2 Dairy Unit and to the Massey/ DSIR sheep group at Palmerston North for quality studies. A very few trials were sown in 1966, a larger number in 1967, 1968 and 1969, and further trials are planned for 1970. Practically all reports at this stage are interim only.

\section{GRAZING TRIAL, PALMERSTON NORTH}

A grazing trial was sown in autumn 1967 comparing $4700+$ 4708 ryegrass (a new tetraploid induced from Ariki) with Huia +4708 . There were three replications of randomized blocks, each paddock being approximately one-tenth acre. The clovers were sown at $3 \mathrm{lb}$ per acre, the ryegrass at $20 \mathrm{lb}$ per acre. Measurement was by cages. The pastures were grazed when 6 to $8 \mathrm{in}$. high. Three hundredweight of superphosphate was applied annually.

Establishment of both grasses and clovers was good and a well-balanced sward was achieved in November 1967. Results for a summer, winter and spring period in 1969, together with the production in the trial for approximately 2 years up to $22 / 9 / 69$, are presented in Table 8 .

In summer and spring there are no significant differences in ryegrass, clover or total production.

In winter, the 4700 sward is significantly better than Huia in ryegrass (35\% increase), clover (163\% increase) and total $(59 \%$ increase $)$.

Over two years, the 4700 sward is not significantly different to Huia in ryegrass, is highly significantly better for clover $(33 \%$ increase) and significantly better $(6 \%$ level) for total $(17 \%$ increase).

\section{DISCUSSION}

From the Mowing Trial winter 1965 (Table 6) it is calculated that, with Manawa ryegrass, the ryegrass most comparable to the 4708 in the Grazing Trial, the 4700 sward had 24\% 
TABLE 8: WHITE CIOVER GRAZING TRIAL, PALMERSTON "N O R T H

(lb Dry Matter Per Acre)

\begin{tabular}{|c|c|c|c|c|c|}
\hline & Variety & Ryegrass & Closer & OS & Total \\
\hline $\begin{array}{l}\text { Summer } \\
21 / 1 / 69 \text { to } \\
24 / 2 / 69\end{array}$ & $\begin{array}{l}\text { Huia } \\
4700\end{array}$ & $\begin{array}{l}808 \\
682\end{array}$ & $\begin{array}{l}412 \\
511\end{array}$ & $\begin{array}{l}13 \\
11\end{array}$ & $\begin{array}{l}1232 \\
1204\end{array}$ \\
\hline $\begin{array}{c}\text { Winter (2 cuts) } \\
27 / 5 / 69 \text { to } \\
1 / 9 / 69\end{array}$ & Huia & $\begin{array}{l}966 \\
1308\end{array}$ & ${ }^{235}{ }^{*}$ & $\begin{array}{l}25 \\
34\end{array}$ & $\begin{array}{l}1226 \\
1960\end{array}$ ** \\
\hline $\begin{array}{l}\text { Spring } \\
1 / 9 / 69 \text { to } \\
22 / 9 / 69\end{array}$ & $\begin{array}{l}\text { Huia } \\
4700\end{array}$ & $\begin{array}{l}826 \\
896\end{array}$ & $\begin{array}{l}188 \\
297\end{array}$ & $\begin{array}{c}16 \\
8\end{array}$ & $\begin{array}{l}1030 \\
1201\end{array}$ \\
\hline $\begin{array}{l}2 \text { Years (25 cuts) } \\
13 / 9 / 67 \text { t o }\end{array}$ & Huia & 17801 & $5816_{* *}$ & 279 & 23903 \\
\hline $22 / 9 / 69$ & 4700 & 18827 & 8746 & 345 & $27918^{\prime}$ \\
\hline
\end{tabular}

more clover than the Huia sward, but it was realized that in this experiment the swards were far more clover dominant' than is usual in a well-managed grazing sward. In the Grazing Trial, the percentage of clover to grass for winter 1969 (from. data Table 8) for the 4700 sward was $13 \%$ higher than the Huia sward. It is considered that this increase in clover content should be acceptable.

From the data of Lambert et al. (1969) for winter production at Gore, May to August 1968 (their Table 4), 4700 clover produced $1.9 \mathrm{lb}$ D.M. per acre per day. Contrast this with the winter production in the Grazing Trial at Palmerston North, reported in this paper in Table 8 for June to August inclusive, where 4700 produced $6.4 \mathrm{lb}$ D.M. per acre per day. This amount of clover production at Palmerston North was associated with a significant increase in both grass production and total production, whereas at Gore the clover production was associated with a significant decrease in ryegrass production compared with the Huia sward. It is likely that the winters at Gore are too long for appreciable value from 4700 .

\section{ACKंNOWLEDGEMENTS}

The author gratefully acknowledges the assistance of officers of the Applied Mathematics Division for analysing data, the co- 
operation and assistance of officers of the Grasslands Division's sub-stations in single plant studies, the release of grazing trial data by C. S. Armstrong, who is a collaborator in this project, and the assistance in many ways of technicians of the Plant Breeding Section over the past 12 years.

\section{REFERENCES}

Barclay, P. C., 1960: Breeding for improved winter pasture production in New Zealand. Proc. 8th int. Grassld Congr.: 47-8. 103 1963: Extending season of growth of pasture. Sheepfmg A.:

Lambert, J. P.; Vartha, E. W.; Harris, A. J., 1969: Progress report on 'Grasslands 4700' white clover. Proc. N .Z. Grassld Ass., 31: 135-42. 